\title{
A FUNÇÃO AMBIENTAL DA PROPRIEDADE: CARÁTER CONCEITUAL PARA A MODULAÇÃO DE CONFLITOS SOCIOAMBIENTAIS
}

\section{THE ENVIRONMENTAL FUNCTION OF PROPERTY: CONCEPTUAL FEATURE FOR SOCIO-ENVIRONMENTAL CONFLICTS MODULATION}

Délton Winter de Carvalho ${ }^{1}$

\section{Resumo}

O presente trabalho tem por escopo analisar a questão envolvendo a matéria florestal e o direito de propriedade. Sabe-se que a relação entre a proteção florestal e o direito de propriedade é extremamente complexa, pois o direito fundamental à propriedade dá ensejo ao exercício de prerrogativas inerentes ao direito subjetivo, porém este deve ser exercido respeitando outros direitos fundamentais de mesma hierarquia constitucional, como o direito ao meio ambiente ecologicamente equilibrado. Nesse sentido, será analisada a estrutura constitucional do direito de propriedade, em suas faces subjetiva e objetiva. Após, será verificada como a função ambiental condiciona o exercício do direito de propriedade, exercendo um caráter modulador dos conflitos entre estas dimensões jusfundamentais, de um lado os deveres ambientais e de outro o direito à propriedade privada. A análise dos elementos semânticos e conceituais da função ambiental fornece critérios interpretativos para ponderação dos interesses em jogo, lembrando, sempre, que estes devem respeitar as premissas estruturais do Estado Constitucional.

Palavras-chave: função ambiental; direito de propriedade; direito ao meio ambiente ecologicamente equilibrado; proteção florestal.

\begin{abstract}
The present work has the scope of analyze the issue involving forest protection and the property rights. It is known that the relationship between forest protection and property rights is extremely complex, since the fundamental right to property gives rise to the exercise of prerogatives inherent in subjective law, but this must be exercised while respecting other fundamental rights of the same constitutional hierarchy, such as the right to an ecologically balanced environment. In this sense, the constitutional structure of the property right, in its subjective and objective face will be analyzed. After that, the environmental function of the property will be verified. It conditions the property right to guarantee the modulatory character of the conflicts between the fundamental dimensions of the right to the ecologically balanced environment and the right to private property. The analysis of the semantic and conceptual elements of the environmental function provides interpretative criteria for weighing the interests at stake, always remembering that they must respect the structural premises of the Constitutional State.
\end{abstract}

Keywords: environmental function; property rights; ecologically balanced environment; forest protection.

\footnotetext{
${ }^{1}$ Doutor em Direito pela UNISINOS - Universidade do Vale do Rio dos Sinos. Professor do Programa de Pós-Graduação em Direito da UNISINOS, nível Mestrado e Doutorado. E-mail: delton@deltoncarvalho.com.br
} 


\section{INTRODUÇÃO}

A matéria florestal apresenta inegável conexão com o exercício do direito de propriedade, uma vez que propriedades cobertas por vegetação podem sofrer restrições e limites ao seu uso e gozo, face aos interesses transindividuais ${ }^{2}$ que permeiam a função ambiental das florestas. O presente artigo apresenta uma reflexão sobre a importância da função ambiental como critério de modulação para a solução de conflitos entre as dimensões jusfundamentais do direito ao meio ambiente e o direito à propriedade privada. Tais análises dar-se-ão a partir de uma matriz analítica da literatura jurídica, orientada pela Teoria do Estado de Direito (Rule of Law), empregando a pesquisa o método de abordagem dedutivo e procedimento histórico e comparativo.

De longa data a matéria florestal vem impondo restrições, no cotidiano econômico e jurídico brasileiro, ao exercício do direito de propriedade e à atividade econômica de forma geral. A inegável condição essencial que as florestas exercem para garantia do equilíbrio ecológico, este assegurado a todos no caput do art. 225 da CF, emana a formação de um sistema jurídico florestal ao longo de décadas no Direito Ambiental brasileiro, num emaranhado regulatório composto por leis, decretos, resoluções, portarias e outros atos normativos. Assim como os demais bens ambientais, a supressão dos recursos florestais pode afetar de diferentes maneiras o resguardo do interesse transindividual, constitucional e infraconstitucionalmente protegido. Essa condição de interesse juridicamente tutelado de natureza transindividual, que os recursos florestais adquirem, decorre diretamente dos benefícios e serviços ecológicos por estes prestados. As florestas e seus atributos são, portanto, elementos essenciais para o equilíbrio ecológico que, por seu turno, tem natureza de bem de uso comum do povo, em virtude de sua essencialidade para a sadia qualidade de vida.

A cobertura vegetal e sua relação com o direito de propriedade pode, portanto, apresentar uma diversidade de aspectos e relações jurídicas, tais como benfeitorias plantadas objeto de contratos e negócios jurídicos, obrigações de reflorestamento propter rem, direito a pagamento por serviços ecossistêmicos, ou mesmo, limitações administrativas ao uso da

\footnotetext{
2 Os interesses transindividuais, muitas vezes referidos como interesses coletivos lato sensu, compreendem os interesses coletivos stricto sensu e os difusos. A distinção entre estas duas espécies (coletivo e difuso) do gênero transindividual consiste na determinação relativa dos titulares (coletivos) o una indeterminação absoluta (difusos). Em um ponto de vista procesual, para ambos os casos, "há a impossibilidade de titularidade individual, pois tais direitos são decorrentes de uma circunstância de fato, no caso dos interesses ou direitos difusos, e uma relação jurídica-base, nos direitos coletivos." (CARVALHO, 2011, p. 337).
} 
propriedade. Tais relações, por evidente, exercem consequências em diversos contextos sociais (econômico, político, jurídico, científico). De outro lado, a propriedade privada consiste em um instituto que realiza um importante acoplamento estrutural entre múltiplos contextos sociais, refletindo o nível de liberdade, de segurança jurídica, de eficiência econômica, de proteção ambiental e de justiça social de uma determinada comunidade. Um sistema frágil de garantia ao direito de propriedade, seja por falhas regulatórias ou mesmo corrupção, tem por consequência um estímulo ao desperdício e à poluição. De outro lado, um sistema sólido de garantia à propriedade privada permite a identificação e a responsabilização dos poluidores assim como incentiva a preservação dos valores (dentre os quais o ambiental é cada vez mais importante) de sua propriedade pelo proprietário (BYRNE, 2005).

Este caráter multifacetado e policontextual torna ainda mais interessante e complexa a análise jurídica das relações entre propriedade e cobertura florestal. Da mesma maneira, o uso da propriedade, seja ela pública ou privada, dá ensejo ao exercício de prerrogativas inerentes ao direito subjetivo, porém em necessária conformação com o resguardo de outras dimensões, tais como a social e a ambiental. Não bastasse, o interesse público pode justificar limitações e restrições ao direito de propriedade, exercendo um caráter limiar entre as dimensões jurídicas subjetivas e deveres transindividuais em jogo na sociedade.

Neste sentido, o presente artigo realiza uma detida reflexão acerca do sentido jurídico de função ambiental da propriedade e o seu caráter modulador dos conflitos entre as dimensões jusfundamentais do direito ao meio ambiente ecologicamente equilibrado e do direito à propriedade privada. Para tanto, há uma necessária reflexão a ser realizada acerca da estrutura constitucional do direito de propriedade, em sua face subjetiva (direito subjetivo) e objetiva (deveres). Em seguida, a análise dos elementos semânticos e conceituais da função ambiental fornece critérios interpretativos para ponderação dos interesses em jogo. Importante destacar que qualquer que seja a construção das respostas a tais conflitos, estas devem partir sempre das premissas estruturais do Estado Constitucional. Eis as perguntas a que este texto se propõe a responder... 


\section{O DIREITO DE PROPRIEDADE E SUA RELAÇÃO COM A PROTEÇÃO FLORESTAL: DIREITO SUBJETIVO E FUNÇÃO}

A Constituição Federal brasileira considera tanto o direito de propriedade (art. 5ㅇ, caput e inciso $\mathrm{XXI}^{3}$ ) como o direito de todos ao meio ambiente ecologicamente equilibrado (art. $225)^{4}$, como direitos fundamentais constitucionais autônomos ${ }^{5}$, tendo-se como consequência direta desta autonomia recíproca a necessidade de um equilíbrio entre estes direitos e seus respectivos deveres, sem possibilidade de uma sobreposição ou hierarquização a priori. As florestas são, inegavelmente, condição para o equilíbrio ecológico assegurado no caput do art. 225 da Constituição Federal, exercendo, de outro lado, significativas limitações ao uso e gozo da propriedade.

A engenharia constitucional desenhou o direito de propriedade privada, como um direito-dever, dotado de caráter fundamental. De tal sorte, o caput do art. $5^{\circ}$ garante a brasileiros e estrangeiros residentes no País a inviolabilidade à propriedade. Esta é assegurada a partir uma dimensão subjetiva, a partir da qual é "garantido o direito de propriedade" (inciso XXII). A sua garantia encontra-se, contudo, condicionada ao dever de que seu exercício se dê em sintonia com uma dimensão comunitária ou objetiva, devendo, para tanto, a propriedade privada "atender à função social" (XXIII). De maneira coerente, a propriedade privada e sua função social consistem em princípios gerais da atividade econômica (art. 170, II e III , CF). A função social da propriedade privada deve ser assegurada tanto em áreas urbanas ${ }^{7}$ como rurais $^{8}$, estando sua delimitação prevista coerentemente no texto constitucional.

\footnotetext{
${ }^{3}$ Art. 5․ Todos são iguais perante a lei, sem distinção de qualquer natureza, garantindo-se aos brasileiros e aos estrangeiros residentes no País a inviolabilidade do direito à vida, à liberdade, à igualdade, à segurança e à propriedade, nos termos seguintes: (...) XXII - é garantido o direito de propriedade."

${ }^{4}$ Os próprios tribunais têm descrito a proteção ambiental como um processo evolutivo dos direitos fundamentais, conforme se observa da jurisprudência mais recente do Supremo Tribunal Federal, em voto do ministro Celso de Mello, em Mandado de Segurança no 22.164-0/SP, j. 30.10.1995.

${ }^{5}$ Segundo o magistério de José Joaquim Gomes Canotilho: "Da mesma forma que deixamos vincada a autonomia do ambiente enquanto bem jurídico, também como direito fundamental ele é protegido com autonomia relativamente a outros direitos que Ihe são <<próximos >> (por exemplo o direito à saúde ou o direito de propriedade)." (CANOTILHO, José Joaquim Gomes (coord.). Introdução ao Direito do Ambiente. Lisboa: Universidade Aberta, 1998. p. 28).

6 "Art. 170. A ordem econômica, fundada na valorização do trabalho humano e na livre iniciativa, tem por fim assegurar a todos existência digna, conforme os ditames da justiça social, observados os seguintes princípios: (...) II - propriedade privada; III - função social da propriedade."

7 "art. 182. $\$ 2^{\circ}$. A propriedade urbana cumpre sua função social quando atende às exigências fundamentais de ordenação da cidade expressas no Plano Diretor."

8 "art. 186. A função social é cumprida quando a propriedade rural atende, simultaneamente, Segundo critérios e graus de exigência estabelecidos em lei, aos seguintes requisites: I - aproveitamento racional e
} 
Em vista do caráter multifacetado do regime da propriedade, mostra-se mais adequado falar-se em propriedades do que seu uso no singular (mais atrelado à ideia física do bem). Lembre-se, neste sentido, que o exercício do direito de propriedade privada é capaz de refletir em uma pluralidade de manifestações do fenômeno jurídico (propriedade intelectual, propriedade industrial, propriedade rural, propriedade urbana, entre outras). Por consequência, há o dever de cumprimento da função social em todas estas dimensões do direito de propriedade privada.

A conformação de tais ditames constitucionais nas relações civis inerentes ao direito de propriedade (uso, gozo, disposição e reivindicação de bens) atribui a este direito contornos de solidariedade social (deveres orientados funcionalmente). Não por outra orientação, o §1ㅇ do art. 1.228 do Código Civil de 2002 prevê, de forma aderente ao sentido constitucional de propriedade privada, que:

"o direito de propriedade deve ser exercido em consonância com as suas finalidades econômicas e sociais e de modo que sejam preservados, de conformidade com o estabelecido em lei especial, a flora, a fauna, as belezas naturais, o equilíbrio ecológico e o patrimônio histórico e artístico, bem como evitada a poluição do ar e das águas." (grifo nosso)

Assim, o direito infraconstitucional, ao refletir a orientação e o design constitucional, assegura a dimensão subjetiva do direito à propriedade, sendo esta a "do ter direito" à propriedade privada. Em outras tintas, a faculdade de usar, gozar, dispor e reivindicar de bens. ${ }^{9}$ De outro lado, o mesmo dispositivo normativo acima transcrito prevê a existência de limites (por meio de deveres) ao exercício deste direito, em face dos interesses transindividuais que devem ser protegidos de uma possível utilização nociva da propriedade. Note-se, para tanto, a determinação de um devido processo legal para a constituição de deveres ambientais legítimos. Segundo este, a conformação dos limites ao uso da propriedade deve se dar em consonância com o estabelecido em lei especial que verse sobre "a flora, a fauna, as belezas naturais, o equilíbrio ecológico e o patrimônio histórico e artístico", impondo-se, ainda, um dever geral de ser "evitada a poluição do ar e das águas."

Assim, nota-se que a propriedade privada passa a apresentar um deslocamento de uma dimensão individualista (direito individual) para uma dimensão econômica (instituto de direito econômico (SILVA, 2007)), funcionalizada para atendimento a interesses comunitários,

adequado; II - utilização adequada dos recursos naturais disponíveis e preservação do meio ambiente; III - observância das disposições que regulam as relações de trabalho; IV - exploração que favoreça o bemestar dos proprietários e dos trabalhadores."

${ }^{9}$ Cfe. caput do art. 1.228 do Código Civil de 2002: "O proprietário tem a faculdade de usar, gozar e dispor da coisa, e o direito de reavê-la do poder de quem quer que injustamente a possua ou detenha." 
adquirindo, por isso, uma dimensão social. Acompanhando lição clássica, pode ser dito que o princípio da função social "transforma a propriedade capitalista, sem socializá-la." (SILVA, 2007, p. 121). A atribuição constitucional de uma função social não desconstitui a propriedade privada, sendo esta também um direito fundamental. No entanto, a funcionalização da propriedade estabelece a introdução de um interesse alheio ao do proprietário, tendo como repercussão imediata não poder ser o direito de propriedade tido como um direito individual (SILVA, 2015), numa acepção de caráter absoluto. A função social modifica, de forma imediata, a natureza da propriedade privada, manifestando-se na configuração estrutural do próprio direito de propriedade, não se tratando apenas de limitações ao exercício deste direito, mas sim numa nova configuração de sua estrutura nuclear e conceitual, como direito (poder) e dever (função).

\section{A FUNÇÃO SOCIAL DA PROPRIEDADE COMO FUNDAMENTO PARA A IMPOSIÇÃO DE DEVERES AO DIREITO DE PROPRIEDADE}

A função social tem como seu pressuposto existencial a propriedade privada, pois não há que se falar em sua aplicação sobre a propriedade pública. Neste sentido, o direito de propriedade consiste em uma moeda com duas faces coerentemente compatíveis, de um lado, trata-se de um direito subjetivo e, de outro, de uma função (GRAU, 2005. p. 241-245). A previsão constitucional estabelece uma necessária conciliação entre a dimensão individual da propriedade e sua relevância social. Para tanto, a propriedade trata-se de um direito subjetivo, porém com uma função necessariamente social, numa circunvisão comunitária. Ainda, a congruência entre o direito subjetivo e a função social retrata-se na análise comparativa entre o momento (i) estático e (ii) dinâmico da propriedade. Neste sentido, a propriedade no momento estático é direito (poder) que acolhe o titular, enquanto que em seu momento dinâmico, de utilização da propriedade, ela é dever (função), "regulada em razão do fim a que socialmente se destina." (GRAU, 2005, p. 244).

À dimensão subjetiva inerente ao proprietário, que é marcada por ter direito à propriedade privada (art. 5ㅇ, XXII, CF), adere uma dimensão impositiva de deveres positivos ${ }^{10} \mathrm{ou}$ negativos $^{11}$, fundada numa dimensão de índole comunitária (interesse público, numa referência mais tradicional). Há, por assim dizer, uma funcionalização do direito subjetivo, visando a um

\footnotetext{
10 STJ, AgRg no REsp no 1138517/MG, 2a Turma, rel. Min. Humberto Martins, DJ 01.09.2011.

${ }^{11}$ BENJAMIN, 2007, p. 113-114.
} 
equilíbrio sistêmico entre individualismo e o bem-estar social, entre segurança jurídica e justiça social. Porém, o princípio da função social não autoriza o esvaziamento do conteúdo essencial mínimo da propriedade sem a respectiva indenização, uma vez estar o direito à propriedade privada também assegurado como direito fundamental e garantia constitucional.

Não obstante seus atributos privados e econômicos, trata-se o direito de propriedade de um direito subjetivo público ${ }^{12}$ com limites impostos objetivamente pela ordem constitucional, face a importância comunitária de outros deveres fundamentais (dimensão coletiva ou sistêmica). Dito de outra forma, pode ser afirmado que o direito de propriedade consiste em um "direito privado de interesse público." (BORGES, 2011, p. 1.303) Há, portanto, uma tutela da propriedade formalmente individual, estando assim asseguradas suas características privadas de exclusividade e perpetuidade, desde que seu exercício esteja alinhado com as exigências materialmente sociais. Não se deve, portanto, compreender a propriedade como comprometida, esvaziada ou mesmo relativizada, mas sim condicionada a fins socialmente relevantes e impositivos de deveres. Porém, tal condicionamento ou funcionalização não deve dar margem a um aniquilamento da dimensão individual e privada da propriedade. Por tais motivos, tem-se o resguardo destes deveres estarem atrelados incondicionalmente ao devido processo legal (art. 5ㅇ, LV, CF). Assim, o telos constitucional não pode jamais servir de justificativa ao pretenso esvaziamento da propriedade privada, mas sim a supressão do seu uso abusivo ou nocivo transindividualmente.

De outro lado, o caráter multifacetado da propriedade não permite que esta tenha seu conteúdo descrito apenas a partir de um elemento ou dimensão. Portanto, no conteúdo da propriedade, há o elemento individual, que possibilita e justifica a dimensão subjetiva individual referente ao uso, gozo e lucro do proprietário. A este aglutinam-se além do fator social, 0 componente ambiental (MACHADO, 1994. p. 127.). A exemplo da função social, a função ambiental da propriedade não se presta a anular sua função individual. Em havendo inconciliável colidência, caberá ao Poder Público lançar mão da desapropriação, sempre como último recurso, em razão da necessária busca por uma conciliação entre os interesses individuais e ambientais (MACHADO, 1994. p. 129.).

Sob o ponto de vista econômico, um regime de propriedade privada estável e seguro, tem a função de estimular que o proprietário seja responsável pela internalização de quaisquer externalidades (tais como poluição ou degradação ambiental em geral), bem como tenha

${ }^{12}$ CANOTILHO, 1995, p. 91. 
estímulos não apenas para explorar economicamente, mas garantir a saúde e equilíbrio ecossistêmico da área objeto de sua propriedade (tal como pode ser relacionado com as propriedades agrícolas, altamente dependentes dos serviços ecossistêmicos).

Assim, a função ambiental da propriedade deve ser estudada com maior atenção, por fomentar um equilíbrio entre a dimensão individualista e patrimonialista inerente ao exercício do direito de propriedade pelo proprietário e a orientação funcional de que este exercício não deva ser pernicioso para os interesses sociais e, nestes, mais especificamente, os ambientais.

\section{FUNÇÃO AMBIENTAL DA PROPRIEDADE}

Tradicionalmente, a propriedade privada era concebida como uma estrutura de relações entre seres humanos. Contudo, o crescimento da escassez e da fragilidade dos recursos naturais sugere que preocupações com a natureza melhor fundamentadas sejam tomadas em consideração pelo próprio conceito de propriedade (quer em suas variáveis individual e coletiva) (WINTER, 2016. p. 3). Assim, a propriedade passa a ser construída não mais como um próprio ("proprius"), envolvendo direitos de usar, destruir e dispor dos ativos, de forma livre e exclusiva, mas, ao contrário, como uma concessão ("mutuum") da natureza, colhendo o rendimento dentro de margens de reprodução e obrigação de preservar o bem para usuários subsequentes (WINTER, 2016, p. 03).

A função ambienta ${ }^{13}$ ou ecológica ${ }^{14}$ da propriedade encontra uma inegável origem no sentido atribuído juridicamente à função social da propriedade privada (art. 5 XXIII, CF), porém com esta não se identifica, detendo autonomia e especificidades. A função social serve, num primeiro momento, de um "pressuposto dogmático" (MIGUEL, 1992, p. 79), sendo a base

\footnotetext{
${ }^{13}$ Como bem elucida lição já clássica de Antônio Herman Benjamin, “(...) três são as características essenciais da função, seja ela privada, seja ela pública: a) é uma atividade, b) exercida como dever-poder e c) em favor de terceiro." (BENJAMIN, 1993, p. 28). Esclarece ainda que "A função ambiental atua sobre um determinado objeto: o bem ambiental. Não se confunda, entretanto, o objeto da função ambiental com seu fim. A função ambiental atua sobre o seu objeto e para concretizar o seu fim (a qualidade ambiental como valor importante da qualidade de vida). $\mathrm{O}$ titular do dever-poder movimenta-se sobre $\mathrm{O}$ objeto, mas sempre finalisticamente orientado" (BENJAMIN, 1993, p. 60). E, finalmente, prolata seu magistério no sentido de que a função ambiental decorre da "qualidade comunal do bem ambiental." (BENJAMIN, 1993, p. p. 82).

${ }^{14}$ A distinção entre função ambiental e a função ecológica é percebida na doutrina nos seguintes termos: “(...) ressalte-se que as funções ecológicas (relativas aos ecossistemas) e ambientais (concernentes às inter-relações existentes no meio, notadamente com a espécie humana) estão claramente explicitadas e interligadas." (MILARÉ, 2015, p. 1.311).
} 
jurídica a partir da qual a função ecológica transforma o direito de propriedade em um direito ao uso limitado do bem, de forma que não lesione o meio ambiente (MIGUEL, 1992. p. 31).

As funções social e ambiental coincidem em sua origem, pois ambas se apresentam como reflexos da orientação funcional do exercício do direito de propriedade, a qual limita seu exercício individual por deveres decorrentes da necessária congruência transindividual dos bens em sociedade. Esta origem comum decorre da funcionalidade da propriedade (MIGUEL, 1992. p. 61), estando esta, por seu turno, atrelada à face objetiva ou comunitária do regime jurídico da propriedade. Ambas dimensões funcionais (social e ambiental) limitam a propriedade como direito subjetivo (interesse individual), a partir da tomada em consideração dos interesses transindividuais potencialmente envolvidos em seu exercício (dimensão dinâmica).

Diversamente da função social, que incide apenas sobre a propriedade privada, a função ambiental submete sua aplicação independentemente do regime de propriedade, público ou privado. ${ }^{15}$ Comparando tais funções, pode ser constatado que, enquanto a função social apresenta-se como uma limitação ao exercício do direito à propriedade privada no contexto social, a função ambiental recai sobre a propriedade em quaisquer regimes em que esta se encontre, público ou privado. Como o direito ao meio ambiente também é um direito subjetivo da personalidade, "(...) a exigibilidade de seu exercício deve verificar-se com independência de quem seja o proprietário da coisa, o Estado ou o particular." (MIGUEL, 1992, p. 34).

Este caráter transversal da função ambiental tem sua origem na própria natureza do bem ambiental e na irradiação específica a este de direitos e deveres. O direito ao meio ambiente ecologicamente equilibrado, previsto no art. 225 da Constituição, assinala uma dimensão transindividual aos bens ambientais que, apesar de apresentar simultaneidade nas dimensões subjetiva (personalíssima) e objetiva (coletiva), transcende a dicotomia público e privado.

O surgimento da função ambiental decorre da constatação de que a fórmula da função social já não é suficiente para descrever adequadamente as relações que, sob o ponto de vista

\footnotetext{
${ }^{15}$ Assim, a especificidade da função ambiental em relação à função social se dá em virtude desta se tratar de um atributo da propriedade privada, especificamente, enquanto que aquela independe do regime jurídico da propriedade, público ou privado. Neste sentido fazem-se as tintas de Paulo de Bessa Antunes: "A função ambiental independe do regime dominial, pois uma floresta, pública ou privada, desempenha a função ambiental, ou não, sem que o status jurídico de seu proprietário seja relevante. Aliás, somente a desatenção a realidade pode ver contradição entre regime de propriedade e proteção ao meio ambiente. Assim, parece-me um despropósito tratar da propriedade, em relação ao seu aspecto ambiental, utilizando-se o já quase centenário conceito da função social da propriedade." (ANTUNES, 2011. p. 33.)
} 
ambiental, tem de um lado terceiros, indivíduos ou sociedade e, de outro, o proprietário. Ainda, tal conceito de função social mostra-se insuficiente para manter o equilíbrio entre os direitos do proprietário e a presença das novas necessidades sociais, dentre as quais destaca-se a ambiental. A insuficiência na abrangência da função social resulta da observação de que esta se projeta como uma forma de limitar o exercício dos poderes do titular em sua relação com os demais, devido ao caráter produtivo do bem sob sua posse.

Em síntese, a função social se manifesta nas repercussões econômicas do uso da propriedade, porém não atende às necessidades inerentes ao caráter limitado dos recursos naturais ou à garantia de facilitação ao usufruto de bens não renováveis e bens ambientais ao maior número de pessoas, sem que isto esvazie o conteúdo da propriedade (MIGUEL, 1992. p. 31). Assim, a função ambiental está comprometida em assegurar que o uso da propriedade privada resguarde os interesses ecológicos, ambientais, paisagísticos e de proteção dos recursos naturais, submetendo o exercício do direito de propriedade às determinações presentes na legislação ambiental. Tudo isto, sem, contudo, um esvaziamento ou aniquilação do direito de propriedade.

O elemento "catalizador" da função ambiental, por evidente, é o meio ambiente (MIGUEL, 1992. p. 31). A função ambiental impõe ao proprietário não apenas um dever de abster-se de determinadas atividades, mas também a obrigações de fazer no sentido de utilização ambientalmente responsável para obtenção de benefícios não apenas econômicos, mas também ambientais. Assim, a função ambiental não está no exterior do direito de propriedade, mas compõe seu conteúdo interno, conceitual e constitutivo. A função ambiental da propriedade não se configura em meras intervenções do Poder Público na propriedade privada, na forma de restrições ou limitações administrativas, compondo a própria definição do direito de propriedade, “(...) não sendo algo que Ihe é exterior, mas como seu próprio conteúdo." (BORGES, 2011, p. 1.308). Em contraposição ao conceito tradicional de propriedade privada, a função ambiental da propriedade deve atribuir ao conteúdo deste direito um dever, inerente e interno, de "(...) restringir danos cumulativos", mantendo um nível que seja ecologicamente sustentável. Trata-se de um dever de evitar degradação, resguardando uma “(...) integridade ecológica” (TAYLOR; GRINLINTON, 2011, p. 09) ao bem objeto da propriedade.

Os direitos de propriedade, como uma relação jurídica permeada pela necessária sustentabilidade, determinam relações de poder entre indivíduos privados e uma gama de "outros". No contexto da apropriação de terras, estes "outros" deve incluir o Estado Regulador, outros proprietários (comunidade de vizinhos e outros proprietários), os sem propriedade 
(publico e futuras gerações) e a natureza (outras espécies e formas de vida) (TAYLOR; GRINLINTON, 2011. p. 10). A função ambiental desta sorte é marcada por impor que o direito subjetivo do proprietário de dispor e usufruir do bem não transcenda as repercussões inerentes à esfera privada, estando este direito limitado pelos deveres de atendimento à dimensão objetiva, de não lesão aos direitos subjetivos alheios ou interesses transindividuais conexos ao imóvel (tais como características ambientais relevantes situadas no imóvel).

Contudo, a função ambiental não permite uma ampla discricionariedade, muito pelo contrário. Diferentemente da função social, amplamente desenvolvida a partir do trabalho interpretativo jurisprudencial, que se revela como importante para a delimitação interpretativa do seu conteúdo, a função ambiental atribui um destaque superior à legislação. Segundo Juan Delgado de Miguel (1992. p. 82), o desenvolvimento da função ambiental na prática se dá pela mão do legislador, a partir de um âmbito dúplice normativo: as perceptivas, que determinam o conjunto de direitos e obrigações que vinculam o proprietário, sob o ponto de vista ambiental; e aquelas tendentes a delimitar o "critério de atuação processual", que permita fornecer aos tribunais padrões para decidir frente aos danos ambientais produzidos com o mínimo de gasto de dinheiro e tempo, para a tutela de um bem que não é apenas particular, mas de toda a sociedade.

\section{A Função ambiental como bem de uso comum do povo}

Importante destacar que a função ambiental decorre da previsão constitucional do bem tutelado como "meio ambiente ecologicamente equilibrado", consistindo em "bem de uso comum", por ser "essencial à sadia qualidade de vida." De tal sorte, se trata de interesse transindividual (difuso ou coletivo), com natureza de bem comunitário.

Não bastasse a previsão normativa, por sua própria natureza, a função ambiental depende da aquisição de um ganho ambiental transindividual (a partir de serviços ecossistêmicos) proporcional e razoável para a imposição de restrições ao direito de propriedade.

A função ambiental atrela-se a uma natureza de bens comunitários (res commune) que, material ou imaterialmente, estão designados na Constituição Federal como "bem de uso comum do povo" em virtude de sua essencialidade para "a sadia qualidade de vida." A Constituição propaga um equilíbrio a partir da noção antropocêntrica da "dignidade da pessoa humana" e seu alargamento correspondente, este consignado na expressão "qualidade de 
vida", numa dimensão ecologicamente equilibrada. Assim, a propriedade e seus atributos devem atender à função ecológica, sendo vedado o seu uso ambientalmente nocivo ou arriscado desproporcionalmente, justificando limitações ao seu uso.

O direito fundamental ao meio ambiente ecologicamente equilibrado apresenta uma dupla natureza de direito-dever, numa racionalidade jurídica-constitucional simultaneamente personalíssima (ou subjetiva) e coletiva (ou objetiva) (CANOTILHO, 1998. p. 27-28; CARVALHO, 2013. p. 44-46). A primeira dimensão tem relação direta com a face constitutiva de ter direito ao ambiente ecologicamente sadio, por meio de um direito subjetivo público. Já a dimensão objetiva (perspectiva sistêmica e transindividual) consiste na imposição dos deveres de proteção justificada na relevância ${ }^{16}$ transindividual e comunitária do bem ambiental (impondo limites à dimensão subjetiva, de usufruto dos bens e serviços ambientais).

Assim, há uma conciliação entre o "direito de todos ao meio ambiente ecologicamente equilibrado" e os deveres constitucionais ambientais ("impondo-se ao poder público e à coletividade de defendê-lo e preservá-Io") impostos aos entes públicos e privados. Esta dimensão coletiva consiste em verdadeira tarefa fundamental do estado, havendo expressamente a atribuição de deveres genéricos de proteção ambiental ao Estado. ${ }^{17}$ Assim, a violação destes ( $\$ 1$ 으, do art. 225), justifica a imputação de responsabilidade civil pelo seu não cumprimento (FENSTERSEIFER, 2010. p. 77-114; STEIGLEDER, 2010. p. 09-38).

Portanto, a função ambiental a ser respeitada pelo exercício da propriedade, pública ou privada, deve ser exercida em conformidade com a orientação legislativa e o seu sopesamento aos demais direitos fundamentais. A função ambiental da propriedade não consiste em um conceito capaz de subjugar qualquer limite ou os demais direitos fundamentais. O simples fato de sua relevância transindividual incontestável e sua natureza de bem de uso comum não dá guarida a uma posição, muito frequente em nossos tribunais e doutrina, de constante sobreposição a priori e sem maiores reflexões técnicas ao Estado de Direito a outros direitos fundamentais.

Desta maneira esta deve ser exercida dentro da legalidade e com o devido equilíbrio com os demais direitos fundamentais, possivelmente em conflito. Assim, a função ambiental, que tem por pressuposto dogmático a função social, a exemplo desta, não se confunde com as

\footnotetext{
${ }^{16}$ Art. 225, caput, da Constituição Federal: "Todos têm o direito ao meio ambiente ecologicamente equilibrado, bem de uso comum do povo e essencial à sadia qualidade de vida, impondo-se ao Poder Público e à coletividade o dever de defendê-lo e preservá-lo para as presentes e futuras gerações."

${ }^{17}$ Art. 225, $\S 1^{\circ}$, da Constituição Federal: "Para assegurar a efetividade desse direito, incumbe ao Poder Público (...)."
} 
limitações administrativas. Enquanto a função ambiental diz respeito a estrutura do direito de propriedade, se tratando de uma característica nuclear ao próprio conceito, o sistema de limitações encontra sentido ao exercício do direito de propriedade, sendo sintetizado na atividade do proprietário.

É desta forma, que a função ambiental impõe o dever de usar a propriedade sem violar o direito de todos ao direito meio ambiente ecologicamente equilibrado, sujeito, em fazendo, à tríade responsabilidade em matéria ambiental (civil ${ }^{18}$, administrativa ${ }^{19}$ e criminal $^{20}$ ).

\section{O papel da função ambiental em matéria florestal: a modulação de respostas aos conflitos entre propriedade privada e a tutela ambiental florestal}

Apesar do caráter aberto da função ambiental como elemento que deve assegurar o benefício transindividual dos serviços ambientais, na condição de bens de uso comum do povo, as restrições ao direito de propriedade motivadas por esta função devem estar alinhadas e condicionadas ao devido processo legal, sob pena de ilegítima abusividade.

Em matéria florestal, o Código Florestal (Lei n 12.651/12) faz referência expressa ao cumprimento da função ambiental no conceito de Área de Preservação Permanente (art. $3^{\circ}, 11$ ), a exemplo do que já ocorria na legislação revogada (Lei $n^{\circ} 4.771 / 65$, art. $1^{\circ}, \S 2^{\circ}$, II). A função ambiental, inegavelmente, exerce uma importante orientação para a realização do processo interpretativo das regras em matéria ambiental, promovendo a harmonização entre o uso sustentável da propriedade privada e a proteção das florestas. Para tanto, deve ser este processo sempre guiado pela premissa de que apenas a lei tem "esse poder de criar normas concernentes a deveres e a direitos de propriedade" (MACHADO, 1994, p. 126). Em síntese, a existência das funções social e ambiental da propriedade não devem acarretar no aniquilamento da função individual desta.

Em nível específico de regulação florestal, a exemplo do papel desempenhado pelo Código Florestal antigo (Lei o 4.771/65), o assim denominado novo Código Florestal (Lei no 12.651/12) cumpre com a finalidade de lei geral florestal para proteção e uso sustentável das florestas. Este desiderato legal é explicitado em seu próprio texto ao prever que sua normatividade recai sobre "a proteção da vegetação, Áreas de Preservação Permanente e áreas

\footnotetext{
${ }^{18}$ Assentada no $\$ 1^{\circ}$ do art. $14^{\circ}$, da Lei $n^{\circ} 6.938 / 81$.

${ }^{19}$ Arts. 70 a 76 da Lei $n^{\circ} 9.605 / 98$ e Decreto Federal $n^{\circ}$ 6.514/08.

${ }^{20}$ Lei $n^{\circ} 9.605 / 98$.
} 
de Reserva Legal; a exploração florestal, o suprimento de matéria-prima florestal, o controle da origem dos produtos florestais e o controle e prevenção dos incêndios florestais, e prevê instrumentos econômicos e financeiros para o alcance de seus objetivos." ${ }^{21}$ Da mesma forma, é a legislação florestal geral que atribui expressamente a condição de bens de interesse comum às florestas ${ }^{22}$ e, por evidente, aos seus serviços e funções ambientais. De outro lado, a legislação florestal consagra como um de seus objetivos a "compatibilização e harmonização entre o uso produtivo da terra e a preservação da água, solo e vegetação" 23 , atendendo à consagração constitucional do meio ambiente e da propriedade como Princípios da Ordem Econômica. ${ }^{24}$

Na condição de regra geral em matéria florestal, é o próprio Código Florestal vigente (Lei no 12.651/12) que faz expressa referência à função ambiental ou ecológica, como elemento constitutivo e justificador da imposição de limitações administrativas ${ }^{25}$ impostas ao direito de propriedade por este estatuto legal. Por se tratarem de intervenções de índole geral e com o escopo de atendimento ao bem-estar social, estas não geram direito a indenização ao proprietário, ${ }^{26}$ motivo pelo qual devem sempre ser submetidas à observância da estrita legalidade e à uma hermenêutica restritiva. No caso das Áreas de Preservação Permanente, estas consistem em áreas (cobertas ou não por vegetação) especialmente protegidas em razão de sua "função ambiental de preservar os recursos hídricos, a paisagem, a estabilidade geológica e a biodiversidade, facilitar o fluxo gênico de fauna e flora, proteger o solo e assegurar o bem-estar das populações humanas." 27

Por seu turno, a função da Reserva Legal é de i) assegurar o uso econômico de modo sustentável dos recursos naturais do imóvel rural, ii) auxiliar a conservação dos processos ecológicos, iii) auxiliar a reabilitação dos processos ecológicos, iv) promover a conservação da biodiversidade, v) promover o abrigo e a proteção de fauna silvestre e da flora nativa, vi)

\footnotetext{
${ }^{21}$ Conforme texto artigo 1ㅇ-A da Lei no 12.651/12.

${ }^{22}$ Conforme art. 2o da Lei no 12.651/12.

${ }^{23}$ Art. 10-A, Lei no 12.651/12.

${ }^{24}$ Art. 170, incisos II, III e VI, CF.

${ }^{25}$ Como é corrente, a matéria das restrições ao direito de propriedade é tratada como intervenção do Estado na propriedade, mais especificamente no que diz respeito ao instituto das limitações administrativas. Em diferenciação a servidão e à desapropriação, a limitação administrativa é "toda a imposição geral, gratuita, unilateral e de ordem pública, condicionadora do exercício de direitos ou de atividades particulares às exigências do bem-estar social." (MEIRELLES, 2015, p. 746).)

${ }^{26}$ Quanto à APP: REsp 1240122/PR, Rel. Ministro Herman Benjamin, Segunda Turma, STJ, j. 28/06/2011, DJe 11/09/2012. No que toca a RL: REsp 1179316/SP, Rel. Ministro Teori Albino Zavascki, Primeira Turma, STJ, j. 15/06/2010, DJe 29/06/2010. E Mata Atlântica: AgRg no REsp 1250992/SP, Rel. Min. Humberto Martins, Segunda Turma, STJ, DJe de 23/04/12.

${ }^{27}$ Art. 3으, II, Lei no 12.651/12.
} 
promover a proteção da fauna silvestre e da flora nativa. ${ }^{28} \mathrm{Em}$ referência aos termos normativos do art. 12 do Código Florestal vigente, nota-se que a função última do instituto da Reserva Legal é assegurar, em imóveis rurais, a proteção de variados biomas brasileiros, por meio da preservação de vegetação florestal nativa em percentuais diversos. Em síntese, à Reserva Legal cumpre uma função ambiental geral de conservação de bancos de dados genéticos de fauna e flora, inerentes aos biomas brasileiros, visando a uma justaposição entre o uso econômico da propriedade e o equilíbrio ecológico.

A título exemplificativo, em nível de regime jurídico específico ao bioma de Mata Atlântica (Lei no 11.428/06), não se mostra difícil a tarefa de desvendar a função ambiental, sendo esta explicitada no objeto deste diploma legal como a "conservação, a proteção, a regeneração e a utilização do Bioma Mata Atlântica." ${ }^{29}$ Uma atenta leitura deste estatuto florestal específico revela sua função ambiental geral, como sendo a de assegurar a manutenção de um banco de dados genéticos inerentes a este bioma. A exemplo do instituto da Reserva Legal, a proteção da Mata Atlântica ${ }^{30}$ tem por orientação de preservação dos materiais genéticos inerentes a biomas brasileiros, sendo que ambos institutos são norteados pela obrigatoriedade de manutenção de áreas a serem preservadas em percentuais, como é o caso das normas constantes nos arts. 12 do Código Florestal ${ }^{31}$ (para Reserva Legal) e 30, II, 31, §1ㅇe e 2ㅇ (para a proteção do bioma da Mata Atlântica nas áreas urbanas e regiões metropolitanas) da Lei do Bioma Mata Atlântica, a título exemplificativo.

\footnotetext{
${ }^{28}$ Art. 3으, III, Lei oㅡ $12.651 / 12$.

${ }^{29}$ Art. 1ㅇ, Lei no 11.428/06.

${ }^{30}$ Apesar da identidade funcional entre estes institutos, inegáveis diferenças existem entre estes. Uma delas é o perfil conservacionista da Reserva Legal, na qual é autorizado o manejo sustentável. No Bioma Mata Atlântica o caráter mostra-se mais preservacionista, permitindo-se uma atuação muito mais reduzida, sendo livre apenas "a coleta de subprodutos florestais tais como frutos, folhas ou sementes, bem como as atividades de uso indireto, desde que não coloquem em risco as espécies da fauna e flora, observando-se as limitações legais específicas e em particular as relativas ao acesso ao patrimônio genético, à proteção e ao acesso ao conhecimento tradicional associado e de biossegurança." (art. 18, Lei no 11.428/06). As Áreas de Preservação Permanente também apresentam um caráter preservacionista. É corrente que o conservacionismo é pautado pelo uso adequado e criterioso dos recursos naturais (wise use), enquanto que o preservacionismo estabelece uma reverência à natureza no sentido de sua valoração estética e espiritual da vida selvagem (no-use). Estas correntes são, na história do ambientalismo norte-americano, lideradas e defendidas por Gifford Pichot e John Muir, respectivamente. 31 "Art. 12. Todo imóvel rural deve manter área com cobertura de vegetação nativa, a título de Reserva Legal, sem prejuízo da aplicação das normas sobre as Áreas de Preservação Permanente, observados os seguintes percentuais mínimos em relação à área do imóvel, excetuados os casos previstos no art. 68 desta Lei: I - localizado na Amazônia Legal: 80\% (oitenta por cento), no imóvel situado em área de florestas; b) 35\% (trinta e cinco por cento), no imóvel situado em área de cerrado; c) 20\% (vinte por cento), no imóvel situado em área de campos gerais; II - localizado nas demais regiões do País: 20\% (vinte por cento)."
} 
Desta forma, tanto a função social como a função ambiental da propriedade não tem por objeto anular a função individual privada desta. Quando inconciliáveis, o Poder Público tem a alternativa de realizar a desapropriação, devendo este instituto ser usado como "último recurso", priorizando-se a conciliação e o equilíbrio entre estas funções (MACHADO, 1994. p. 129.). O exercício da função ambiental é orientado e prioritariamente legitimado por um devido processo legal, no qual cabe ao proprietário o exercício do seu direito subjetivo a propriedade, nos limites impostos pelos deveres ambientais de não ocasionar lesão ao bem ambiental (degradação ambiental individual ou coletiva, sob pena de responsabilização civil ambiental, conforme art. 14, $\$ 1$, da Lei n. 6.938/81) e de respeitar as limitações administrativas de ordem ambiental, estando a sua incidência sobre um dado imóvel condicionada às previsões legais inerentes aos regimes especiais de proteção ${ }^{32}$, tais como a Lei no 12.651/12, Lei no 11.482/06, Lei no 9.985/00, entre outros.

\section{PRESSUPOSTOS INTERPRETATIVOS CONSTITUCIONAIS PARA A SOLUÇÃO DE CONFLITOS ENTRE DIREITO DE PROPRIEDADE E A PROTEÇÃO AMBIENTAL}

Sabido que as constituições modernas, dentre as quais encontram-se a brasileira, vêm codificando, cada vez mais, direitos que em certa medida são efetiva e realmente conflitantes (CANOTILHO, 2013. p. 37). Uma destas dimensões, constantemente em tensão e conflito, consiste nas interfaces entre o direito de propriedade e o bem constitucional "ambiente".

Não raras vezes em nossa doutrina e jurisprudência, conflitos entre a dimensão individual da propriedade e interesses ambientais são resolvidos com uma simplificação interpretativa que remete à "supremacia dos interesses coletivos sobre os individuais." Para esta respeitável corrente teórica e jurisprudencial, os interesses coletivos devem sempre prevalecer quando em conflito com direitos e garantias individuais. Esta posição argumentativa tem por premissa uma concepção hierarquizada de determinados direitos, tidos como preferenciais em detrimento de outros. Esta influente concepção em nosso sistema jurídico encontra como um de seus maiores defensores o ilustre administrativista Celso Antônio Bandeira de Mello (2008, p. 69), para quem a supremacia do interesse público sobre o privado “(...) trata-se de um verdadeiro axioma reconhecível no moderno Direito Público. Proclama a superioridade do interesse da coletividade, firmando a prevalência dele sobre o do particular,

${ }^{32}$ Termo que tomamos de BORGES (2011, p. 1.314). 
como condição, até mesmo, da sobrevivência e asseguramento deste último. É pressuposto de uma ordem social." Para o insigne autor, a aplicação deste princípio no campo da Administração teria por consequência "a posição privilegiada do órgão encarregado de zelar pelo interesse público e de exprimi-lo, nas relações com os particulares" e a "posição de supremacia do órgão nas mesmas relações." (MELLO, 2008, p. 70).

Esta corrente encontra uma grave assimetria acerca das motivações e fundamentos constitucionais para a escolha desta supremacia ou sobreposição. Em síntese, esta mostra-se constantemente assentada na justificativa de que os interesses coletivos são dotados de uma dimensão mais difusa e, portanto, mais "essencial" ao bem comum, justificando uma posição de prevalência a priori e em abstrato.

Como consequência da autonomia recíproca entre os direitos fundamentais, nosso sistema constitucional não parece abrigar este critério de prevalência de uns direitos sobre outros, quer de interesses coletivos sobre os direitos individuais, nem de direitos individuais sobre interesses coletivos. Muito pelo contrário, o texto constitucional é hígido em estabelecer um modelo que pugna pelo equilíbrio e pela equidade entre as dimensões de direitos $e$ garantias individuais e a tutela dos interesses coletivos. Assim, o sistema constitucional pátrio “(...) não elege qualquer um dos direitos nela consagrados a <<direito fundamental supremo>> (terminologia italiana), e não nos parece que, em sede hermenêutica e argumentativa, seja possível demonstrar que um direito é supremo relativamente a outro em qualquer condição ou circunstância." (CANOTILHO 2013, p. 37).

Em face da estrutura adotada pela Constituição de 1988, não assiste assento ao entendimento de erigir ao direito de propriedade um caráter absoluto e hierarquicamente superior ao meio ambiente, o que permitiria o seu uso social e ambientalmente abusivo. Da mesma forma, o inverso também é verdadeiro, pois “(...) não basta proclamar a jusfundamentalidade própria do direito ao ambiente, do direito à saúde ou do direito à qualidade de vida para, sem qualquer esforço de argumentação e de ponderação, proclamar o seu caráter preferente e absoluto." (CANOTILHO 2013, p. 37).

Em se tratando de direitos de uma mesma posição, ambos dotados de jusfundamentalidade, a solução para a colisão entre estes deve ser sustentada em parâmetros decisionais mais afetos à técnica jurídica inerente à juridicidade estatal ou, em outras tintas, aos pilares estruturantes do Estado de Direito (rule of law). Esta perspectiva por evidente mostra-se mais complexa por exigir uma maior "transparência argumentativa" e um maior 
aprofundamento sobre a dogmática, mantendo-se um respeito e a ambas as posições e interesses em jogo.

Assim, em detrimento da supremacia do interesse público deve haver o deslocamento para um sistema de ponderação de interesses que, em se tratando de direitos fundamentais, envolvem uma análise de proporcionalidade na solução dos conflitos, a partir da compreensão de que a decisão em favor de uma dimensão jusfundamental sobre a outra em um dado conflito deve ser feita, com o menor comprometimento do direito fundamental sucumbente. Esta ponderação deve ser concreta e sistematicamente orientada (ÁVILA, 2001, passim).

Adentrando nesta perspectiva, observa-se que a proteção ambiental e o direito de propriedade apresentam uma dignidade constitucional equivalente e equidistante, sem a sobreposição apriorística de um sobre outro. Ao elevar a dignidade da pessoa humana como princípio fundamental, o texto constitucional “(...) estabeleceu uma relação de equilíbrio entre o coletivo e o individual, repudiando, de forma cabal, a supremacia de uns em detrimento de outros." (ANTUNES, 2011, p. 37, 158-159).

Nem poderia ter-se outra concepção a partir das luzes emanadas do Estado de Direito (ambiental, social, democrático), pois é a sua juridicidade que, simultaneamente, legitima a proteção e a responsabilização em matéria ambiental, determinando também o limite. A tênue construção destes limites deve ser feita a partir do critério técnico-jurídico de como esta tutela se dará, quando a tutela do bem ambiental estiver em conflito com outros direitos fundamentais, num devido processo legal (due proces of law). Assim, a tutela ambiental, erigida a bem de uso comum por sua característica de ser essencial a sadia qualidade de vida, deve ser, quando em conflito com o direito de propriedade (garantia fundamental, art. 5, caput, CF), exercida com a observação aos princípios do Estado de Direito: segurança jurídica, reserva da lei, devido processo legal. Tais dimensões, longe de serem meros entraves formais ao direito ao ambiente sadio, consistem em institutos essenciais a qualquer Estado Democrático de Direito, afastando os riscos de um autoritarismo ecológico ${ }^{33}$ ou uma ecoxiismo ${ }^{34}$ (tutela ambiental sem respeito aos pressupostos principiológicos e legais inerentes ao próprio Estado de Direito). Cumpre destacar, ainda, que a tutela ambiental também depende de uma previsibilidade e segurança jurídica, sob pena de estar sujeita exclusivamente aos humores dos tribunais e à discricionariedade administrativa dos órgãos administrativos ambientais.

\footnotetext{
33 José Joaquim Gomes Canotilho critica o que este denomina "integrismo ambiental autoritário." (CANOTILHO, 2013. p. 33)

${ }^{34}$ Expressão tomada do autor supra (CANOTILHO, 1995. p. 73).
} 
Não se pode olvidar que a segurança jurídica, além de um pressuposto para o próprio resguardo ao direito de propriedade, também é condição para uma tutela ambiental que estabeleça segurança e validade quer para os atos administrativos de fiscalização e punitivos (autos de infração e respectivas sanções administrativas) quer para os atos autorizativos (licenças, outorgas e autorizações ambientais). De tal sorte, a segurança jurídica consiste em um pressuposto aos regimes democráticos, seja no exercício do direito-poder ambiental ou mesmo no direito de propriedade (como direito subjetivo e função). Ao final, é o Estado de Direito (rule of law) que permite os critérios para solução de conflitos entre diversas dimensões de direitos fundamentais. Por tal razão, uma análise dogmático-jurídica mostra-se necessária dos critérios constitucionais que servem de orientação para a solução de conflitos desta ordem no Estado Democrático de Direito.

\section{ESTADO DE DIREITO E A JURIDICIDADE EM CASOS DE CONFLITOS ENTRE DIREITO DE PROPRIEDADE E OS BENS AMBIENTAIS}

Os princípios da segurança jurídica e da proteção da confiança ${ }^{35}$ existem como exteriorização de garantia, pelo Estado de Direito, de determinados direitos fundamentais, tais direito de propriedade, direito adquirido e iniciativa econômica. Importante destacar que a rule of law norte americana, equivalente ao nosso Estado de Direito ${ }^{36}$, descreve o direito de propriedade como um direito econômico e democrático, por criar uma certa segurança e independência do cidadão frente ao Estado, atuando positivamente como condição para o exercício de seu papel em regimes democráticos (SUNSTEIN, 1991. p. 18).

De forma resumida, o Estado de Direito é frequentemente compreendido a partir de quatro características. Primeiro, que os poderes estatais devem ser exercidos por meio de regras previamente promulgadas e de aplicação geral. Segundo, as regras são justificadas mais

\footnotetext{
${ }^{35}$ Garantidos no Brasil pelo art. 5o, XXXVI, da CF: "A lei não prejudicará o direito adquirido, ato jurídico perfeito e da coisa julgada."

${ }^{36}$ Em didático magistério José Joaquim Gomes Canotilho assenta as bases da construção do sentido de Estado de Direito, a partir de uma análise da Common Law (rule of law) e da tradição da civil law (Rechtsstaat): "A ideia de um Estado domesticado pelo direito alicerçou-se paulatinamente nos Estados ocidentais de acordo com as circunstâncias e condições concretas existentes nos vários países da Europa e, depois, no continente americano. Na Inglaterra sedimentou-se a ideia de rule of law (<<regra do direito > ou <<império do direito >>). Na França emergiu a exigência do Estado de legalidade (État legal). Dos Estados Unidos chegou-nos a exigência do Estado constitucional, ou seja, o Estado sujeito a uma constituição. Na Alemanha construiu-se o princípio do Estado de direito (Rechtsstaat), isto é, um Estado subordinado ao direito." (CANOTILHO, 1999, p. 24)
} 
por razões legais do que extralegais. Terceiro, regras devem vincular todos os membros do governo, não estando "ninguém acima da lei." Quarto, a aplicação das leis deve ser administrada por um judiciário independente e imparcial (TARLOCK, 2002. p. 585-586).

O Estado de Direito compreende, assim, uma dupla função básica no sentido de impor restrições aos governos, por meio das leis vigentes (exigindo a conformação a estas e imponto limitações ao próprio poder legislativo) e manter ordem e coordenar comportamentos e transações entre os cidadãos. ${ }^{37}$ Assim, o império do direito (rule of law) tem como um de seus benefícios estruturantes a promoção da certeza, previsibilidade e segurança nas relações entre cidadãos e governo (vertical) e naquelas dos próprios cidadãos entre si (TAMANAHA, 2007. p. 08.).

Desta forma, a garantia ao direito de propriedade privada no Estado de Direito significa uma proteção de natureza jusfundamental (art. 5o, caput, XXII) da propriedade contra a expropriação e intervenção estatal ilegítima, naquilo que se convencionou por chamar inviolabilidade da propriedade privada. Ainda, a proteção da propriedade é garantida contra expropriações sem a respectiva indenização (desapropriação). Neste sentido, o inciso XXIV do art. $5^{30}$ prevê a existência de uma proteção procedimental da propriedade privada, descrita como uma garantia ao cidadão de que esta não será expropriada de forma arbitrária, por motivos irrelevantes ou discriminatórios (SUNSTEIN, 1991. p. 18).

Por evidente, existem também as limitações ao exercício absoluto da propriedade privada ou pública, consistente, como já visto, nas funções social (incidente sobre a primeira) e a ambiental (incidente sobre ambas). Estas dimensões funcionais estabelecem um equilíbrio de contenção ao exercício do direito de propriedade, modulando seu exercício pelo interesse público, de ordem social ou mesmo ambiental. No entanto, no conflito entre estas dimensões jusfundamentais não deve, a priori, haver qualquer sobreposição hierarquizada. Até mesmo por que, como delimita José Joaquim Gomes Canotilho (2013, p. 283), “(...) num plano estritamente hermenêutico-constitucional, parece-nos que se deve acentuar uma orientação que se reconduza ao seguinte ponto de partida heurístico: as normas constitucionais (regras e princípios) devem interpretar-se sob reserva de outras normas constitucionais colidentes."

\footnotetext{
${ }^{37}$ Como o próprio autor (TAMANAHA, 2007, p. 03-07) menciona neste texto, esta é uma concepção básica (concisa) da rule of law, emitida a partir dos pontos de maior convergência conceitual na doutrina. 38 "XXIV - A lei estabelecerá o procedimento para desapropriação por necessidade ou utilidade pública, ou por interesse social, mediante justa e prévia indenização em dinheiro, ressalvados os casos previstos nesta Constituição."
} 
As limitações ao direito de propriedade no interesse da coletividade devem guardar um equilíbrio assegurado constitucionalmente. Para tanto, estas limitações devem ser impostas de forma adequada a alcançar os objetivos desejados e necessários para a tutela ambiental, mas sem significar um ônus exagerado e insuportável, capaz de esvaziar o direito de propriedade. Equilíbrio este que lança para a juridicidade os critérios de solução dos conflitos envolvendo o exercício do direito de propriedade e a tutela dos bens ambientais. Também, é na tripartição dos poderes que se justifica a relevância da reserva da lei como critério definidor do devido processo legal e limites para a solução dos conflitos existentes entre estas dimensões jusfundamentais.

Inegável constatar que uma visão ecológica desafia fundamentalmente o direito de propriedade clássico (SAX, 1992. p. 1.439), neste sentido cabe um papel fundamental ao Estado de Direito para modular o equilíbrio protetivo entre os serviços e funções ambientais ${ }^{39} \mathrm{com}$ a garantia da inviolabilidade da propriedade privada. Para tanto, o sistema constitucional pátrio ressalva uma necessidade de definição destes espaços a serem especialmente protegidos a partir da qual “(...) a alteração e a supressão permitidas somente através de lei, vedada qualquer utilização que comprometa a integridade dos atributos que justifiquem sua proteção." 40

Portanto, a legalidade exerce um fator de equilíbrio e segurança ao processo democrático, constitucionalmente estabelecido, delimitando os critérios tanto para a ambição protetiva transindividual exarada na Constituição, e personificada nas funções social e ambiental, como para o resguardo à inviolabilidade da propriedade privada. Adquire, assim, fundamental relevância a tripartição dos poderes (art. 2o da $\mathrm{CF}^{41}$ ) que, por meio do Princípio da Legalidade, fornece parâmetros seguros e previsíveis para a solução de conflitos entre direitos de igual dignidade constitucional.

O Estado de Direito tem por máxima no direito inglês a noção aristotélica de que é “(...) preferível um direito de regras a um direito de homens", imperando a ideia de rule of law, not of men. Em clássico texto sobre o Estado de Direito e a dicotomia entre regras gerais ("general rule of law") e a discricionariedade pessoal ("personal discretion to do justice"), Antonin Scalia (1989, p. 1176) anota que “(...) em um sistema democrático, a regra geral tem crédito especial à

\footnotetext{
${ }^{39}$ Cabe chamar atenção para o texto previsto no I, do $\S 1^{\circ}$, do art. $225, \mathrm{CF}$, que diz: "§ $1^{\circ}$ : Para assegurar a efetividade desse direito, incumbe ao Poder Público: 1 - preservar e restaurar os processos ecológicos essenciais e prover o manejo ecológico das espécies e ecossistemas; (...)

${ }^{40} \mathrm{Cfe}$. Inciso III, $\S 1^{\circ}$, art. 225, CF.

41 "São poderes da União, independentes e harmônicos entre si, o Legislativo, o Executivo e o Judiciário."
} 
preferência, uma vez que trata-se de um produto proveniente daquele setor governamental mais reativo à coletividade." E o autor prossegue conclusivamente, que enquanto "a administração pública e juízes lidam com casos individuais; os legisladores generalizam." ${ }^{22} \mathrm{O}$ já falecido Justice da US Supreme Court vai além e prolata ainda que "(...) legislações que estabeleçam regras de inadequada clareza ou precisão são criticadas, na condição de não serem democráticas - e, de forma extrema, inconstitucional - pois estas deixam muito a ser decidido por pessoas diversas daquelas que ganham um mandato popular de representatividade política."

Exatamente pela necessidade de estabilidade e previsibilidade, o sistema constitucional atribui uma importante função e o devido respeito ao Princípio da Legalidade, estabelecendo que "ninguém será obrigado a fazer ou deixar de fazer alguma coisa senão em virtude de lei" (art. 5, II, CF). Grifamos a referência constitucional expressa à lei, e não a decretos, regulamentos, portarias, resoluções, instruções, e outros atos regulamentares. Trata-se, pois, da explicitação da subordinação da atividade administrativa à lei (SUNSTEIN, 1991. p. 03), sendo esta prevista especificamente no caput, do art. $37 \mathrm{CF}$, estando a eficácia de toda a atividade administrativa condicionada ao atendimento da lei e do direito (MEIRELLES, 2015. p. 90).

Fornecendo a compreensão do sentido a ser atribuído à "legalidade", Celso Antonio Bandeira de Mello (2007, p. 76-77) descreve que esta deve ser entendida como conformação à lei e, sucessivamente, às subsequentes normas regulamentares que, com base na primeira, a própria Administração expeça para regular a sua própria discricionariedade. Assim, a juridicidade emana uma resposta jurídica aos conflitos sociais que tenham por sustentação leis, regulamentos, princípios e dispositivos constitucionais e precedentes de índole orientadora do sistema.

Porém, a justaposição destes elementos normativos exige uma atenta análise da adequada técnica colocada em questão, sobretudo quando em conflitos envolvendo o direito de propriedade e tutela ambiental, devendo-se atentar para as orientações legais e constitucionais. Não por outra razão o processo legislativo é disposto na Constituição a partir de uma hierarquia estruturante, determinando o condicionamento de matérias e assuntos

\footnotetext{
42 Como é sabido, na Common Law a produção de regras gerais é prioritariamente realizada pelo processo judicial, havendo, contudo, matérias constitucionalmente reservadas ao Congresso.
} 
condicionados a cada um dos níveis legislativos previstos no texto do art. 59 da Constituição Federal. ${ }^{43}$

Há, em casos de conflituosidade envolvendo proteção ambiental e o direito de propriedade, uma constante de que as restrições ao direito propriedade devem ser objeto de interpretação restritiva, conforme orienta o sistema constitucional, em atendimento à proteção da confiança e da segurança jurídica. A restrição ao direito de propriedade tem como condição a existência de lei em sentido estrito, verdadeiro pressuposto democrático (participação do processo legislativo) e para a necessária estabilidade (segurança jurídica e proteção da confiança). Ainda, como já visto, o direito a propriedade é visto comumente como um direito político, uma vez que reduz a dependência do estado e cria uma espécie de segurança, esta indispensável para uma cidadania genuína em regimes democráticos.

Em nosso sistema constitucional, a restrição ao direito de propriedade encontra-se condicionada à reserva da lei, dependendo esta da existência de legislação em sentido estrito ou parlamentar. Em conformidade com o Título IV (Da Organização dos Poderes), Capítulo I (Do Poder Legislativo), Seção VIII (Do Processo Legislativo), Subseção III (Das Leis), o art. 68 prolata que:

"As leis delegadas serão elaboradas pelo Presidente da República, que
deverá solicitar a delegação ao Congresso Nacional. §1o. Não serão
objeto de delegação os atos de competência exclusiva do Congresso
Nacional, os de competência exclusiva do Congresso Nacional, os de
competência privativa da Câmara dos Deputados ou do Senado Federal, a
matéria reservada à lei complementar, nem a legislação sobre: I -
organização do Poder Judiciário e do Ministério Público, a carreira e a
garantia de seus membros; II - nacionalidade, cidadania, direitos
individuais, políticos e eleitorais; III - planos plurianuais, diretrizes
orçamentárias e orçamentos." (grifamos)

Portanto, a regra constitucional é a indelegabilidade no que tange direitos individuais. 0 cuidado do texto constitucional, no que atos de delegação da competência legislativa ao Executivo se fez presente no art. 25, do Ato das Disposições Constitucionais Transitórias. ${ }^{44}$

Note-se que os direitos individuais não podem ser objeto de delegação, tratando-se de matéria reservada ao Poder Legislativo, sendo vedada a sua delegação ao Poder Executivo. De

\footnotetext{
43 "Art. 59. O processo legislativo compreende a elaboração de: | - emendas à Constituição; || - leis complementares; III - leis ordinárias; IV - leis delegadas; V - medidas provisórias; VI - decretos legislativos; VII - resoluções. Parágrafo único. Lei complementar disporá sobre a elaboração, redação, alteração e consolidação das leis."

44 "Art. 25. Ficam revogados, a partir de cento e oitenta dias da promulgação da Constituição, sujeito este prazo a prorrogação por lei, todos os dispositivos legais que atribuam ou deleguem a órgão do Poder Executivo competência assinalada pela Constituição ao Congresso Nacional, especialmente no que tange a: I - ação normativa; II - alocação ou transferência de recursos de qualquer espécie."
} 
tal forma, pode ser dito que o direito de propriedade consiste em matéria reservada à lei. Em matéria de propriedade privada, o poder regulamentar ${ }^{45}$ tem apenas uma função executiva e instrumental de como os ditames legais devem ser aplicados, sem poder alargar as restrições ao direito individual de propriedade. Por isso, cabe acompanhar o já clássico magistério de que “[o]s regulamentos só poderão dispor sobre propriedade privada se forem de absoluta fidelidade à lei, isto é, se respeitarem estritamente o conteúdo e os limites do direito de propriedade dados pela lei." (MACHADO, 1994, 126).

Por evidente, a lesão causada a terceiros ou ao meio ambiente por intermédio do exercício abusivo do direito de propriedade enseja o autor às respectivas responsabilizações (cível, administrativa e criminal). De outro lado, o Poder Executivo permanece com um poderdever de antecipação e imposição de restrições ao exercício do direito de propriedade, porém tais restrições devem encontrar origem na lei parlamentar. A Administração Ambiental, portanto, deve guardar respeito à aplicação da lei e seu conteúdo normativo, estando impedida, contudo, de exercer esse poder para criar deveres e a direitos de propriedade (MACHADO, 1994, 126), que não aqueles já albergados em uma lei parlamentar.

A matéria ambiental não está alheia ao sistema constitucional pátrio, uma vez que se trata de um ramo jurídico e, portanto, depende dos elementos e estruturas inerentes ao Direito. Ao regular relações ambientais, este ramo jurídico o faz, sempre, mediante seus elementos internos, numa operacionalidade fechada, sendo sensível cognitivamente às ressonâncias e irritações decorrentes dos demais sistemas sociais (política, economia, ciência). A própria proteção ambiental, também de índole constitucional, privilegiou a legalidade ao prever, no art. 225, §1으, III, que qualquer alteração ou supressão aos espaços territoriais especialmente protegidos e seus componentes somente possa se dar "através de lei", sendo vedada qualquer utilização que comprometa a integridade de seus atributos. Outro exemplo,

\footnotetext{
${ }^{45}$ Conforme José Afonso da Silva: "Poder regulamentar é a faculdade de expedir regulamentos para fiel execução das leis federais que a Constituição outorga ao presidente da República. Trata-se de poder administrativo, no exercício de função de caráter normativo subordinado. Na realidade, o exercício desse poder permite ao presidente da República cumprir sua função executiva no que tem de mais característico: execução da lei. Chama-se, com efeito, "regulamento" o decreto que consigna um conjunto ordenado de normas destinadas à melhor execução da lei, ou ao melhor exercício de uma atribuição ou faculdade consagrada expressamente na Constituição.(...) O poder regulamentar não é poder legislativo, por conseguinte não pode criar normatividade que inove a ordem jurídica. (...) 0 regulamento tem limites decorrentes do direito positive. Deve respeitar os textos constitucionais, a lei regulamentada e a legislação, em geral, e as fontes subsidiárias a que ela se reporta." (SILVA, 2007. p. 484.)
} 
consiste na necessidade de lei para definição acerca da instalação de usinas que operem com reator nuclear (art. 225, §6ㅇ). ${ }^{46}$

As relações civis que envolvem o exercício do direito de propriedade também delimitam a necessidade de que a atribuição de deveres em virtude de interesses ambientais deva se dar por lei, esta compreendida em sentido estrito. Este é o conteúdo normativo fornecido pelo $§ 1$ o do art. 1.228 do Código Civil de 2002, ao prever expressamente que "o direito de propriedade deve ser exercido em consonância com as suas finalidades econômicas e sociais e de modo que sejam preservados, de conformidade com o estabelecido em lei especial, a flora, a fauna, as belezas naturais, o equilíbrio ecológico e o patrimônio histórico e artístico, bem como evitada a poluição do ar e das águas." (grifo nosso)

Portanto, tanto o direito de propriedade quanto a proteção ambiental lançam mão da lei para "definir os seus contornos, suas necessidades e aspirações" (MACHADO, 1994. p. 126). Estes direitos-deveres estarão, idealmente, alinhados e fortalecendo-se mutuamente. Contudo, quando em inconciliável colisão, deve haver um processo de confrontação das normas jurídicas inerentes a cada um destes institutos, a fim de estabelecer qual deverá, no caso, ser priorizado e deter a supremacia.

De tal maneira, pode ser dito que apenas a lei tem o poder de inovar (fonte primária de direito) no sistema jurídico, criando direitos e deveres, cabendo aos demais atos normativos (decretos legislativos, resoluções, portarias, instruções normativas), um caráter secundário (fonte secundária), jamais podendo contrariar as primeiras (limitando ou ampliando os direitos, deveres, obrigações, pretensões e exceções). Os regulamentos se limitam a determinar a maneira em que as regras legais devem ser observadas e cumpridas. Assim, atos regulamentares isolados não podem produzir normas constitutivas, modificativas ou extintivas de direitos e obrigações (imposições de fazer ou não fazer) diferentes daqueles já previstos em lei. Em nível de direito comparado, Gerd Winter (2016, p. 18) aponta que a maioria dos países da União Europeia, assim como a Corte Europeia de Direitos Humanos, requerem que qualquer intervenção em posições de proprietários deva ser, necessariamente, baseada em legislação parlamentar, perseguindo interesse público, sempre com respeito ao Princípio da Proporcionalidade.

\footnotetext{
${ }^{46}$ Neste sentido Paulo Affonso Leme Machado (1994, p. 126) ensina que "Direito de propriedade e direito do meio ambiente utilizam, pois, a lei para definir seus contornos, suas necessidades e suas aspirações. Esses direitos-deveres podem ajustar-se e estar conciliados, mas se estiverem em colisão, teremos que confrontar as normas jurídicas que cada um desses institutos, para saber qual deles deverá ter a prioridade ou a supremacia.".
} 
De tal forma, o proprietário deve saber de forma clara e antecipada, quais os direitos e deveres que recaem sobre a sua propriedade e possíveis consequências. Deve, portanto, haver a inviolável garantia do proprietário saber qual restrição, seu conteúdo e o momento em esta recai sobre o seu direito de propriedade. Há em tais prerrogativas, a garantia constitucional à segurança jurídica e ao tratamento isonômico frente à lei.

\section{CONSIDERAÇÕES FINAIS}

Apesar do sistema constitucional apontar para uma inadmissibilidade de prevalência apriorística de determinados direitos em detrimento de outros, situados em uma mesma dignidade constitucional, o seu texto institui, de outro lado, um padrão hierárquico para solução de conflitos decorrentes da colisão entre atos normativos. Assim, não há hierarquia entre direitos e deveres, mas sim entre atos normativos de naturezas diversas.

Em matéria de conflitos entre o direito de propriedade e a proteção de bens ambientais há, no Direito Ambiental brasileiro, uma constante de sobrevaloração de instrumentos normativos de hierarquia inferior sobre a lei em sentido estrito, o que por evidente desatende à orientação constitucional. Conforme enfrentado no presente estudo, em se tratando de solução de conflitos entre posições jusfundamentais equivalentes, os critérios aplicáveis devem ser aqueles estabelecidos no próprio sistema jurídico constitucional (sendo esta uma de suas funções primordiais), não podendo a matéria ambiental simplesmente se sobrepor, de forma geral, apriorística e abstrata, às demais dimensões jurídicas, também dotadas de caráter fundamental. Está-se a falar das fronteiras deste ramo jurídico com os demais, em suas intersecções sistêmicas.

Em matéria de conflitos que digam respeito ao exercício do direito de propriedade e a proteção ambiental, não raras vezes há uma tolerância com a "criação" de deveres e restrições ambientais por atos normativos diversos das leis parlamentares (tais como Decretos, resoluções, portarias). Estes posicionamentos geralmente justificam suas posições em simplificações interpretativas tais como a supremacia do interesse público sobre o privado ou na sobreposição da norma supostamente mais restritiva ambientalmente, desconsiderando, assim, o sistema de critérios e competências previsto constitucionalmente. Este posicionamento olvida a própria importância do direito de propriedade privada para a proteção ambiental, seja como um facilitador para identificação dos responsáveis, como um estímulo para a proteção dos atributos do patrimônio individual pelo próprio proprietário, como 
elemento de indução a comportamentos de uso racional da propriedade, e como instituto canalizador de atribuição de responsabilidade (administrativa e civil) ao proprietário por passivos florestais na condição de obrigações "propter rem".

Como se está diante de um conflito entre direitos fundamentais autônomos, mais relevância deve ser atribuída ao devido processo e aos critérios legais estabelecidos pela Constituição. Este é o caso da hierarquia dos atos normativos, prevista no art. 59 da CF. Porém, nem todos conflitos poderão ser solucionados apenas a partir de uma confrontação normativa, isto é, tendo como base a análise da hierarquia dos atos normativos. É neste sentido que ganha destaque um aprofundamento sobre a função ambiental da propriedade que, como elemento modulador, exerce a incumbência de orientar o processo interpretativo na solução dos conflitos entre o exercício da propriedade e os deveres de proteção ambiental.

A função ambiental não apenas encontra uma sustentação constitucional, como atua também como um pilar que permeia toda a legislação florestal infraconstitucional. Com um nítido escopo de orientar critérios racionais para promover o equilíbrio entre o exercício dos direitos de propriedade e os deveres de proteção ambiental, a função ambiental da propriedade orienta e promove um devido processo de racionalização substantiva e procedimental.

A partir de seus caracteres conceituais, a função ambiental deve aumentar a sensibilidade jurídica à escassez dos recursos ambientais e, portanto, delimitar restrições razoáveis e proporcionais ao direito de propriedade. É pela própria delimitação legal que a função ambiental encontra seu conceito e função moduladora, sobretudo nos dispositivos do Código Florestal brasileiro. Seu conceito normativo exerce, assim, a formação de critérios para que tais conflitos sejam sensíveis em compreender se as restrições encontram justificativa e motivação ambiental para sua incidência. De outro lado, a função ambiental serve de importante fundamento para a aplicação destas restrições para uma obtenção mais eficaz e protetiva dos serviços ecossistêmicos em áreas especialmente protegidas ou dotadas de atributos essenciais. Ainda, seu conceito e atributos legais determinam uma maior importância para as análises de custos e benefícios assim como para a integridade ambiental de áreas com especial relevância ecossistêmica. Finalmente, a função ambiental passa a ser um critério dotado de grande relevância para determinar a internalização dos serviços ecossistêmicos nos feixes de direitos e deveres atinentes às intersecções entre direito de propriedade e a proteção ambiental. 
Em síntese, mesmo ante a inegável relevância da função ambiental da propriedade, esta, como critério modulador de conflitos, não pode servir quer como elemento para decisões insuficientemente protetivas, nem como arbitrárias ou excessivas. Lembre-se que este conceito deve se prestar ao atento cumprimento dos ditames e parâmetros legais, devendo a imposição de restrições ao direito de propriedade ser permeado por um due process of law, cauteloso e orientado pelo necessário equilíbrio entre estes dois direitos subjetivos públicos ${ }^{47}$ constitucionalmente assegurados: de um lado, a proteção ambiental e, de outro, o direito à propriedade privada. Assim, a função ambiental não apenas enfatiza o devido respeito às normas legais, estando também prevista em lei, como atua como um elemento modulador da interpretação inerente aos conflitos entre estas dimensões jusfundamentais.

\section{BIBLIOGRAFIA}

ANTUNES, Paulo de Bessa. Áreas Protegidas e Propriedade Constitucional. São Paulo: Atlas, 2011.

ÁVILA, Humberto. "Repensando 'o Princípio da Supremacia do Interesse Público sobre o Particular'." Revista Diálogo Jurídico. v. 1, n. 7, Salvador: CAJ, 2001.

BENJAMIN, Antonio Herman. "Constitucionalização do ambiente e ecologização da constituição brasileira." In: José Joaquim Gomes Canotilho; José Rubens Morato Leite. Direito Constitucional Ambiental Brasileiro. São Paulo: Saraiva, 2007.

"Função Ambiental." In: BENJAMIN, Antonio Herman. (coord.). Dano Ambiental: prevenção, reparação e repressão. São Paulo: Revista dos Tribunais, 1993.

BORGES, Roxana Cardoso Brasileiro. "Função Ambiental da Propriedade." In: Édis Milaré; Paulo Affonso Leme Machado. Doutrinas Essenciais Direito Ambiental. V. II, São Paulo: Revista dos Tribunais, 2011.

BYRNE, J. Peter. "Property and Environment: Thoughts on an Evolving Relationship." Harvard Journal of Law \& Public Policy. v. 28. Cambridge: Harvard University Press, 2005.

CANOTILHO, José Joaquim Gomes (Coord.). Introdução ao Direito do Ambiente. Lisboa: Universidade Aberta, 1998.

"Juridicização da Ecologia ou Ecologização do Direito." Revista Jurídica do Urbanismo e do Ambiente. no 4, Lisboa: IDUAL, dezembro, 1995.

\footnotetext{
${ }^{47}$ Como ensina José Joaquim Gomes Canotilho (1995, p. 91): “Como se sabe, o direito subjectivo público é, em geral, definido como o poder jurídico reconhecido ao particular - sobretudo através de normas de direito público - que lhe permite exigir das autoridades públicas um determinado comportamento para a prossecução de interesses privados."
} 
"Para Natura, Inovação e Tecnologia de Produtos Ltda. (Parecer)." In: ROSSI, Fernando F. et. al. (Coord.). Aspectos controvertidos do direito ambiental: tutela material e tutela processual. Belo Horizonte: Fórum, 2013.

Estado de Direito. Lisboa: Gradiva, 1999.

Parecer Jurídico: direito adquirido, ato jurídico perfeito, coisa julgada, matéria ambiental. São Paulo: Universidade Secovi/SP, 2013.

Protecção do Ambiente e Direito de Propriedade. Coimbra: Coimbra, 1995.

CARVALHO, Délton Winter de. Dano Ambiental Futuro: a responsabilidade civil pelo risco ambiental. Porto Alegre: Livraria do Advogado, 2013.

"A proteção jurisdiccional do meio ambiente: uma relação jurídica comunitária." In: Édis Milaré; Paulo Affonso Leme Machado (orgs.). Doutrinas Essenciais Direito Ambiental. vol. IV. São Paulo: Revista dos Tribunais, 2011.

DANTAS, Marcelo Buzaglo. "Algumas reflexões sobre a aplicação prática do princípio da legalidade em matéria ambiental." In: SOUZA, Maria Cláudia da Silva Antunes de; VIEIRA, Ricardo Stanziola (orgs.). Constitucionalismo Ambiental e Sustentabilidade. Itajaí: Univali, 2015.

Direito Ambiental de Conflitos. Rio de Janeiro: Lumen Juris, 2015.

FARIAS, Cristiano Chaves de; ROSENVALD, Nelson. Curso de Direito Civil: direitos reais. 5a ed. Vol. 5, Salvador: Juspodium, 2012.

FENSTERSEIFER, Tiago. "Responsabilidade do Estado pelos danos às pessoas atingidas pelos desastres ambientais ocasionados pelas mudanças climáticas: uma análise à luz dos deveres de proteção ambiental do Estado e da correspondente proibição de insuficiência na tutela do direito fundamental ao ambiente." In: Direito e Mudanças Climáticas 2: Responsabilidade Civil e Mudanças Climáticas. Paula Lavratti; Vânesca Buzelato Prestes (orgs.). São Paulo: Instituto o Direito por um Planeta Verde, 2010.

GRAU, Eros Roberto. A Ordem Econômica na Constituição de 1988. 10a ed. São Paulo: Malheiros, 2005.

MACHADO, Paulo Affonso Leme. Estudos de Direito Ambiental. São Paulo: Malheiros, 1994.

MEIRELLES, Hely Lopes. Direito Administrativo Brasileiro. 41aed. São Paulo: Malheiros, 2015.

MELLO, Celso Antônio Bandeira de. Curso de Direito Administrativo. 25a ed. São Paulo: Malheiros, 2007.

MIGUEL, Juan Delgado de. Derecho Agrario Ambiental: Propiedad y Ecología. Pamplona: Arazandi, 1992.

MILARÉ, Édis. Direito do Ambiente. São Paulo: Revista dos Tribunais, 10ąed. São Paulo: Revista dos Tribunais, 2015.

SANTOS, Maria Luiza Werneck dos. "Considerações sobre os limites da competência normativa do CONAMA." Revista dos Tribunais. vol. 799, Maio, 2002. 
SAX, Joseph L.. "Property Rights and the Economy of Nature: Understanding Lucas v. South Carolina Coastal Council." Stanford Law Review. n. 45, 1992.

SCALIA, Antonin. "The Rule of Law s a Law of Rules." University of Chicago Law Review. v. 56, no 4, article 1, Chicago: University of Chicago, 1989.

SILVA, José Afonso da. Comentário Contextual à Constituição. 4a ed. São Paulo: Malheiros, 2007. Direito Urbanístico Brasileiro. 7ạ ed. São Paulo: Malheiros, 2015.

STEIGLEDER, Annelise Monteiro. "A imputação da responsabilidade civil por danos ambientais associados às mudanças climáticas." In: Direito e Mudanças Climáticas 2: Responsabilidade Civil e Mudanças Climáticas. Paula Lavratti; Vânesca Buzelato Prestes (orgs.). São Paulo: Instituto o Direito por um Planeta Verde, 2010.

SUNSTEIN, Cass. "On Property and Constitutionalism". Law and Economics Working Papers. no 3, University of Chicago, 1991.

TAMANAHA, Brian. "A Concise Guide to the Rule of Law." Legal Studies Research Paper Series. Paper n. 07, New York: St. John's University, 2007.

TAYLOR, Prue; GRINLINTON, David. "Property Rights and Sustainability: Toward a New Vision of Property." In: David Grinlinton, Prue Taylor. Property Rights and Sustainability. Leiden/Boston: Martinus Nijhoff, 2011.

WINTER, Gerd. "Proporty and Environmental Protection: an overview." In: Gerd Winter (ed.). Property and Environmental Protection in Europe. Groningen/Amsterdam: Europa Law Publishing, 2016.

Trabalho enviado em 06 de março de 2018.

Aceito em 10 de maio de 2018. 